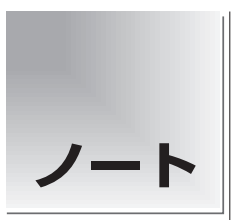

論文受付 2010年 4 月1日

論文受理

2010年12月23日

Code No. 261

\section{SPIO 造影剂投与後の骨䯣における MR 信号を捉えるための評価法}

\author{
琴浦規子 ${ }^{1)}$ ・坂本 清1) $^{1)}$ 福田有子 ${ }^{2,3)}$ ・石藏礼一2 \\ 榎 卓也 ${ }^{1)} \cdot$ 山下達也 $^{1)} \cdot$ 中江保夫 $^{1)}$ \\ 1 ) 兵庫医科大学病院中央放射線部 \\ 2)兵庫医科大学放射線医学教室 \\ 3)現 ルードビッヒマクシミリアン大学
}

\section{緒 言}

Magnetic resonance image(MRI)の肝臓造影検査では, 肝細網内皮を標的とする肝臓特異性 MRI 造影剤で ある超常磁性酸化鉄粒子 (SPIO: super paramagnetic iron oxide)が使用されている ${ }^{1 \sim 4)}$. 超常磁性酸化鉄粒子造 影剤(以下 SPIO 造影剤)は，投与後に主として肝臓に 依存する細網内皮系組織(Kupffer 細胞)に特異的に 取り込まれ， $T_{2}$ 強調画像で正常肝組織の信号を著明に 低下させ，腫瘍組織では信号低下が起こらないこと から病巣検出能を向上させることが知られている5).
更に，SPIO 造影剤の応用として，Tsudaらは病態モ デルウサギを用いた研究で，骨髄中の腫瘍検出，腫 瘍骨転移と炎症性骨病変との鑑別診断の可能性があ ることを報告している6)。また, Fukudaらは人体に応 用し，信号雑音比(SNR: signal-to-noise ratio)による評価 では, SPIO 造影剤投与後 3 時間で正常骨髄の信号 が最も低下し，骨髄転移と炎症性骨病変に信号差が 生じることを報告している7).

本稿では，画像比較のみでは診断が困難となる場 合がある骨髄転移と炎症性骨病変において, SPIO 造

\title{
Evaluation of Magnetic Resonance Signal Intensity in Bone Marrow after Administration of Super Paramagnetic Iron Oxide (SPIO)
}

\author{
Noriko Kotoura,") Kiyoshi Sakamoto,') Yuko Fukuda, ${ }^{2,3)}$ Reiichi Ishikura, ${ }^{2)}$ Takuya Enoki, \\ Tatsuya Yamashita, and Yasuo Nakae') \\ 1 ) Department of Clinical Radiology, Hyogo College of Medicine \\ 2) Department of Radiology. Hyogo College of Medicine \\ 3) Current address: Ludwig-Maximilians-University Munich \\ Received April 1,2010; Revision accepted December 23,2010; Code No. 261
}

\section{Summary}

Super paramagnetic iron oxide (SPIO) is taken up in the bone marrow and lymph nodes, as well as by the liver. Focusing on the intervertebral disks, which are unaffected by contrast effects, we examined the relationship between magnetic resonance image (MRI) signal intensity after SPIO uptake in the vertebral body and intervertebral disks and investigated MRI signal intensity in bone marrow metastases and osteomyelitic (inflammatory) lesions after SPIO uptake by bone marrow. The lumbar spine was imaged in 5 healthy volunteers (age range, 26-48 years). A specified amount of SPIO was administered intravenously, and signal intensities before and after administration were measured. The signal intensity ratio with respect to the value before administration was calculated, and quantitative signal analysis was conducted. A similar investigation was performed in patients with bone metastasis and osteomyelitis. As a result of the metastasis, the signal intensity ratio showed a low value in comparison with normal marrow, and the osteomyelitis showed a high value in comparison with normal marrow. We report the usefulness of evaluations of changes in marrow signal intensity using SPIO in MRI.

Key words: super paramagnetic iron oxide (SPIO), bone marrow, intervertebral disk, magnetic resonance image (MRI), signal intensity ratio 
影剤を用いてその診断精度を高めることを目的に評 価法を検討した。人体で造影効果の影響を受けない 椎間板 ${ }^{8}$ に着目し, SPIO 造影剤取り込み後の椎体と 椎間板の信号值の関係を調べ, SPIO 造影剂の取り込 み率が低い骨髄系9) での SPIO 造影剂投与後の骨髄 信号変化を捉える評価法を考案したので報告する.

\section{1. 理 論}

\section{1-1 SPIO 造影剤取り込みの機序}

SPIO 造影剤は, 酸化第一鉄 $\mathrm{FeO}$, 酸化第二鉄 $\mathrm{Fe}_{2} \mathrm{O}_{3}$ の混合物の結晶 core(径 $5 \mathrm{~nm}$ 程度)が dextran や carboxydextran を支持体として多数結合し, 全体の大きさが数 10 数 $100 \mathrm{~nm}$ の粒子を構成している ${ }^{2}$. 肝臓, 脾臓, リンパ節，肺などの細網内皮系では，貪食細胞により 細菌や異物の処理が行われ, 肝臓では類洞壁細胞に ある Kupffer 細胞が, 骨髄では破骨細胞(毛細血管内 皮細胞)が担当するといわれている ${ }^{10)}$.

動物実験によると, 生体へ取り込まれたSPIO 造影 剤は, 肝臓に $80 \%$, 脾臓に8〜9\%, 残りは骨髄, リン パ節などに分布すると報告されている9 . 静脈注射さ れたSPIO 造影剤は, SPIO 粒子が血中の細菌と結合し て, 投与量の約 $80 \%$ が肝臓において肝細網内皮に領 食される11). SPIO 造影剤は, Kupffer 細胞内では lysosome 顆粒に集積して cluster を形成する。 大きい cluster は局所磁場を乱して $\mathrm{T}_{2}$ *を短縮して肝臓の信 号強度を低下させる ${ }^{12)}$. また小さい cluster は水分子 の magnetic center への接近を容易とし， $\mathrm{T}_{1}$ および $\mathrm{T}_{2}$ を短縮する ${ }^{13)}$. SPIO 造影剂の $\mathrm{T}_{2}{ }^{*}, \mathrm{~T}_{2}$ 短縮効果は 非常に強力で, 通常は $\mathrm{T}_{2}{ }^{*}, \mathrm{~T}_{2}$ 強調画像で使用され $3^{14)}$.

骨髄では，静脈注射された SPIO 造影剂の SPIO 粒 子は, 血中の細菌と結合した後, 破骨細胞により貪食 される, 正常骨髄や炎症性骨病変の骨髄では, 破骨 細胞が存在するため SPIO 粒子は食食され, 信号低下 を招くが，腫瘍や骨転移が存在する箇所では荟食作 用は働かず，信号低下が生じない。このことにより， SPIO 造影剂の骨䯣への揁取率は肝臟に比べて少な いが，骨髄においても，肝臓と同様の機序による造影 効果が期待され, 骨髄中の腫瘍や骨転移病変と炎症 性骨病変の鑑別診断が可能となる.

\section{1-2 評価法}

MRI の画像評価法としては SNR やコントラスト雑音比 (CNR: contrast-to-noise ratio)が多用されており, 客観的な評価法として定着している ${ }^{15 \sim 18)}$. しかし, 実験系では field-of-view(FOV)内に基準信号を得る 関心領域(ROI: region of interest)を設定することがで きるが，臨床系では撮像時間やアーチファクトを考慮

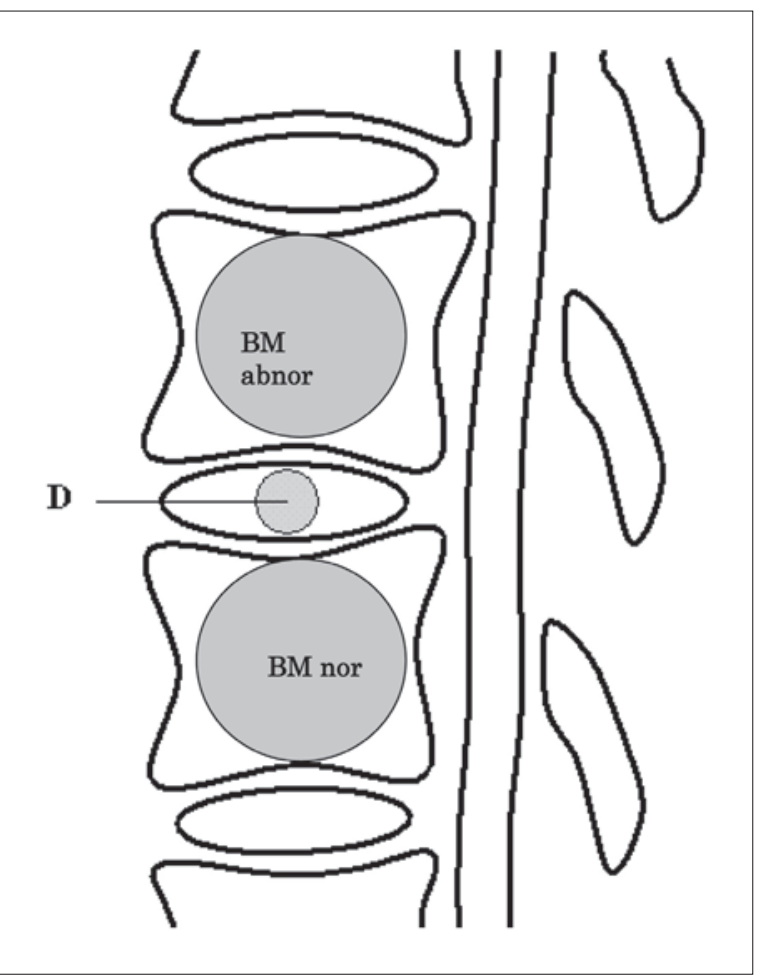

Fig. 1 Setting of ROI in a vertebral body and an intervertebral disk.

$\mathrm{BM}_{\text {nor }}$ is a normal vertebral body region, $\mathrm{BM}_{\mathrm{abnor}}$ is an abnormal vertebral body region, and $D$ is an intervertebral disk.

して FOV 設定が正方形でなく長方形となり，FOV 内 が被写体で占領されてしまうことが多いため，バック グラウンドの信号が正確に得られないことがあり，必 ずしもこれらによる評価が可能とはいえない，した がって，臨床による評価では，基準信号を得る領域 の選択が重要となる，椎間板は，血管性に乏しく造 影効果の影響が少ないと考えられるため ${ }^{8)}$ ，基準信号 を得る領域を設定するのに適した蔵器と考えられる.

われわれは, SPIO 造影剂投与後の骨髄信号変化 を捉えるための評価法として，椎間板からの信号を 基準信号とする評価法を提案する. Short-TI inversion recovery (STIR)により脊椎の撮像を行い，得られ た矢状断面画像に対し正常椎体部 $\left(\mathrm{BM}_{\mathrm{nor}}\right)$, 異常椎体 部 $\left(\mathrm{BM}_{\mathrm{abnor}}\right)$ および椎間板 $(\mathrm{D})$ に ROI を設定し信号值 を計測する(Fig. 1)。計測值を Michelson のコントラ スト ${ }^{19)}$ を用いた次式に代入し，正常椎体部および異 常椎体部の信号強度比： signal intensity ratio $\left(\mathrm{SIR}_{\mathrm{nor}}\right.$, $\left.\mathrm{SIR}_{\mathrm{abnor}}\right)$ を求める。ただし, 異常椎体部とは $\mathrm{T}_{1}$ 強調 画像では低信号強度, $\mathrm{T}_{2}$ 強調画像では中程度から高 信号強度を呈する椎体とした。

$$
\begin{aligned}
& \mathrm{SIR}_{\text {nor }}=\left|\mathrm{D}-\mathrm{BM}_{\text {nor }}\right| /\left(\mathrm{D}+\mathrm{BM}_{\text {nor }}\right) \\
& \mathrm{SIR}_{\text {abnor }}=\left|\mathrm{D}-\mathrm{BM}_{\text {abnor }}\right| /\left(\mathrm{D}+\mathrm{BM}_{\text {abnor }}\right)
\end{aligned}
$$


次に, 被検者にSPIO 造影剤を投与し, 一定時間 経過後に撮像された画像に対し同様の計測を行う.

$$
\mathrm{SIR}_{\text {hour_nor }}=\mid \mathrm{D}_{\text {hour }}-\mathrm{BM} \text { hour_nor } \mid /\left(\mathrm{D}_{\text {hour }}+\mathrm{BM}_{\text {hour_nor }}\right)
$$

$\mathrm{SIR}_{\text {hour_abnor }}=\left|\mathrm{D}_{\text {hour }}-\mathrm{BM}_{\text {hour_abnor }}\right| /\left(\mathrm{D}_{\text {hour }}+\mathrm{BM}_{\text {hour_abnor }}\right)$

ここで, SIR hour_nor, SIR hour_abnor, $\mathrm{D}_{\text {hour }}, \mathrm{BM}_{\text {hour_nor, }}$ $\mathrm{BM}_{\text {hour_abnor }}$ は, それぞれ造影後の正常椎体部の信号 強度比, 異常椎体部の信号強度比, 椎間板の信号強度, 正常椎体部の信号強度, 異常椎体部の信号強度である.

\section{2. 使用機器}

装置は Philips 社製 Gyroscan Intera 1.5 T の spine coil (5チャンネル)を使用した，造影剂はバイエル薬品社製 Ferucarbotran(SPIO 造影剤)を規定量である $8 \mu \mathrm{mol} \mathrm{Fe} /$ $\mathrm{kg}$ を参考に使用した.

\section{3. 方 法}

本学倫理委員会承認(倫理審査承認番号 284)のもと 放射線科医の説明のうえ, 同意を得られた健常ボラン ティアおよび疌椎炎と春椎腫瘍(骨髄転移)の患者に 対し, 造影前の撮像抢よび規定量の SPIO 造影剤投与 後の撮像を行い, 信号強度を計測して評価を行った。

\section{3-1 健常ボランティアの撮影}

健常ボランティア 5 名(26〜48 歳：男性 4 名, 女 性 1 名)に対し, SPIO 造影剤投与前と, 投与後 3, 6，9，24，48 時間ごとの腰椎部の撮像を行った. SPIO 造影剤は, 右前腕部から規定量 $(8 \mu \mathrm{mol} \mathrm{Fe} / \mathrm{kg})$ を静脈投与した。受信用コイルは, spine coil(5 チャ ンネル）用いた。使用シーケンスはFukudaらの用 いた7)STIR とし，スキャンパラメー夕は multi-shot IR (MS-IR), turbo spin echo(TSE), TSE-factor : 7, repetition time (TR): $3000 \mathrm{~ms}$, echo time(TE) : $60 \mathrm{~ms}$, inversion time $(\mathrm{TI}): 170 \mathrm{~ms}$, slice thickness : $4 \mathrm{~mm}$, matrix size : $400 \times 512$ (scan percentage $60 \%$ ), FOV : $300 \mathrm{~mm}$, scan time : $3.06 \mathrm{~min}$ である. 撮像方向は矢 状断像とした.

信号測定部位として第 1 腰椎から第 5 腰椎の椎体 部 $\left(\mathrm{BM}_{\mathrm{nor}}\right)$ お よび第 3 腰椎と第 4 腰椎の椎間板部 $(\mathrm{D})$ にROIを設定し，各撮像タイミングでの信号強度の 平均值を測定した， ROI の大きさは，椎体部，椎間板 部ともに上端と下端に内接する円形とした．このとき， ROI 面積は, 椎体部で $3.0 \sim 4.2 \mathrm{~cm}^{2}$, 椎間板部で $0.23 \sim 0.53 \mathrm{~cm}^{2}$ であった.

各撮像夕イミング( $3 ， 6 ， 9 ， 24 ， 48$ 時間)で得られた 画像から測定した $\mathrm{BM}_{\text {nor }}$ と D から，(1)，（3）式を用い
て SPIO 造影剂投与前に対する投与後の信号強度比： SIR を算出した。また，本法による有用性を評価する ために，CNR 測定法の組織間測定法である空中信号 法 ${ }^{15}$ 18) と, 本稿で提案する方法との比較を行った。 空 中信号法の計算式を(5)式に示す.

$$
\mathrm{CNR}=(\pi / 2) 1 / 2|(\mathrm{D}-\mathrm{BM})| \mathrm{M}_{\text {back ground }}
$$

健常ボランティア 5 名の SIRについては, 一対の 標本による平均の $\mathrm{t}$ 検定を用いて有意な差があるか 検定を行った。

\section{3-2 臨床における検討}

5 名の脊椎炎(圧迫骨折, 結核性脊椎炎, 化膿性脊 椎炎) 患者( 49 75 歳: 男性 3 名, 女性 2 名) と 3 名の 脊椎腫瘍(骨髄転移) 患者 (54 78 歳: 男性 3 名) に, 規定量の SPIO 造影剤 $(8 \mu \mathrm{mol} \mathrm{Fe} / \mathrm{kg})$ を右前腕部から 静脈投与し，健常ボランティアと同様の撮像を行った. ただし，6時間以降の撮像は臨床的に困難であったため， 撮像タイミングは投与前と投与後 3 時間とし，(3)，(4) 式を用いて SPIO 造影剤投与前に対する投与後の信 号強度比：SIR を算出した。

また，これらの結果についても 3-1 と同様の $\mathrm{t}$ 検定 を用いて有意な差があるか検定を行った。

\section{3-3 再現性と位置依存性の検証}

SPIO 造影剤を使用する本法では，単純撮像，造影 剂投与後撮像の間に時間を要するため, 被写体の出 し入れを行う必要があり, 測定值の再現性が重要と なる。同一被験者について，入室から撮像までの工 程を 4 回繰り返して実施し, ポジショニングによる再 現性を検証した。測定部位を第 3 腰椎と第 4 腰椎と して，その信号值の変動を評価した.

また，測定值の変動は，被検者のセット位置に影響 されることが考えられるため, 位置依存性についても 検証した。硫酸銅溶液 (demi water $1000 \mathrm{ml}+\mathrm{CuSO}_{4} 5 \mathrm{H}_{2} \mathrm{O}$ $770 \mathrm{ml}+\mathrm{NaCl} 2000 \mathrm{mg}$ : $\mathrm{T}_{1}$ 值 $407 \mathrm{~ms}, \mathrm{~T}_{2}$ 值 $330 \mathrm{~ms}$ ) を 満たした直径 $15 \mathrm{~cm}$ の円柱ファントムに, オリーブオイ ル $\left(\mathrm{T}_{1}\right.$ 值 $250 \mathrm{~ms}, \mathrm{~T}_{2}$ 值 $52 \mathrm{~ms}$ ) とモル濃度 $0.0025 \mathrm{~mol} / \mathrm{l}$ の Gd-DTPA(gadolinium diethylenetriamine pentaacetic acid： $\mathrm{T}_{1}$ 值 $70 \mathrm{~ms}, \mathrm{~T}_{2}$ 值 $45 \mathrm{~ms}$ ) 溶液を封入し, ファントム中心が磁場中心となるように位置決めをし て撮像した(Fig. 2)。この位置を基準にファントム中心 が磁場中心から横方向(水平方向), 縦方向(垂直方向) に $1 \mathrm{~cm}$ ずつ $3 \mathrm{~cm}$ までファントムを移動し, 信号值の 変化を調べた

再現性における結果においては，2 標本を使った 分散の $\mathrm{F}$ 検定を用いて，等分散であるか検定を行った 撮像条件はそれぞれ 3-1 と同一とした。 


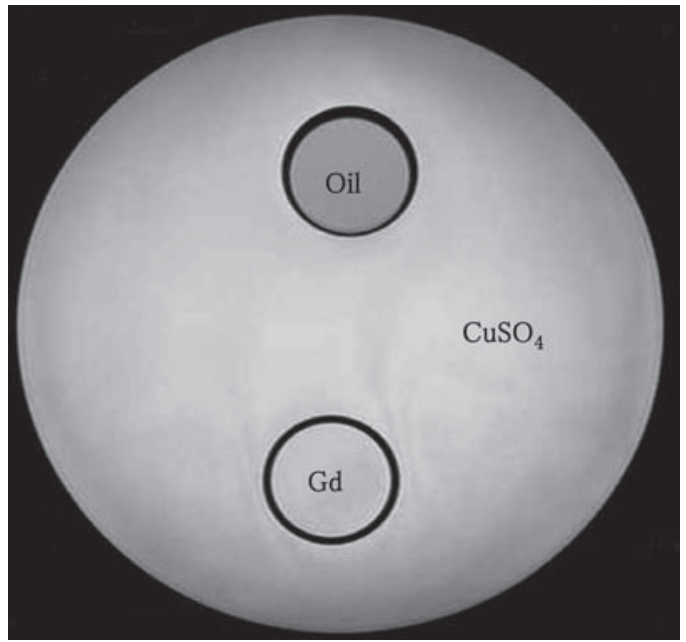

Fig. 2 Phantom that was used for position dependence evaluation; (CuSO 4 : copper sulfate solution, Gd-DTPA: diluted to 0.0025 mol/l Gd-DTPA, Oil: olive oil).

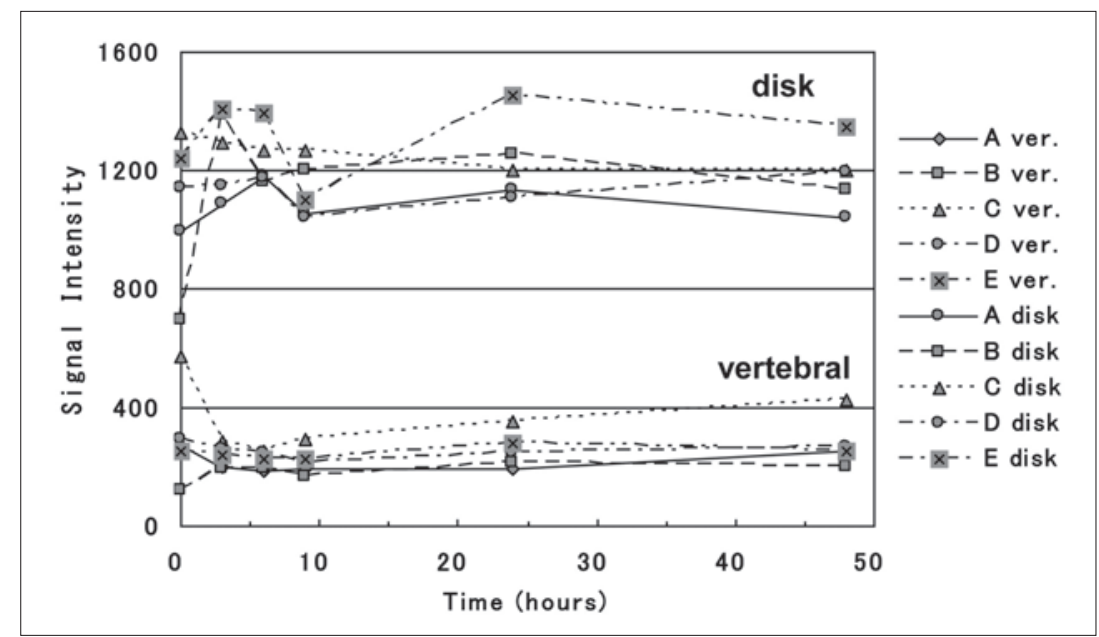

Fig. 3 A signal intensity change after the SPIO administration of a vertebral body and an intervertebral disk.

Signal intensity was measured before the administration of SPIO for five volunteers $(A, B, C, D, E)$, and it was measured after the administration for 48 hours (The signal intensity of a vertebral body part displays the mean of the fifth lumbar vertebrae from the first).

\section{4. 結 果}

\section{4-1 健常ボランティアでの信号值の測定}

第 1 腰椎から第 5 腰椎の測定結果の平均值と第 $3 /$ 第 4 腰椎の椎間板の測定結果を Fig. 3 に示す．椎体 の信号值は200〜300を示し，椎間板の信号值は 1200 程度を示したが, 変動が激しく, 造影剤投与に よる信号増減の傾向は掴めなかった(Fig. 3). 式(1) (4)に従って椎間板と椎体の信号值の差を用いて処理 した結果を Fig. 4 に示す.

処理によって信号強度の変化が現れ，SPIO 造影剤 の取り込みの多寡を示す SIR は, SPIO 投与後 3 時間 から 6 時間にピークを示し，その後徐々に低下した。 ピーク值は, 最小が 1.07 , 最大が 1.68 であり, 固体 差による影響がみられたＳIR は時間とともに低下し たが，48 時間経っても初期の值に戻らないものが あった。
各ボランティアにおける第 1 腰椎から第 5 腰椎を対 象とした空中信号法での CNR の平均值変化を Fig. 5 に示す。本法ではすべてのボランティアで SPIO 造影 剂投与後にSIRの上昇がみられた $(\mathrm{p}<0.06)$ が，空中 信号法ではその傾向にばらつきがあった。また， 24 時間後以降の評価は，空中信号法による CNR，本法 ともに回復傾向であった。

\section{4-2＼cjkstart臨床における検討}

代表的な症例として，結核性骨髄炎症例および骨髄 転移症例における SPIO 造影剂投与前と投与後の撮 像画像を Fig. 6 に示す。また, その測定結果を Fig. 7 に示す，ROI は，結核性骨髄炎症例では正常椎体の 第 1 腰椎椎体部と病変部の第 5 腰椎椎体部に, 骨髄 転移症例では病変部の第 10,12 胸椎椎体部と正常 椎体の第 1 腰椎椎体部に設定した. 


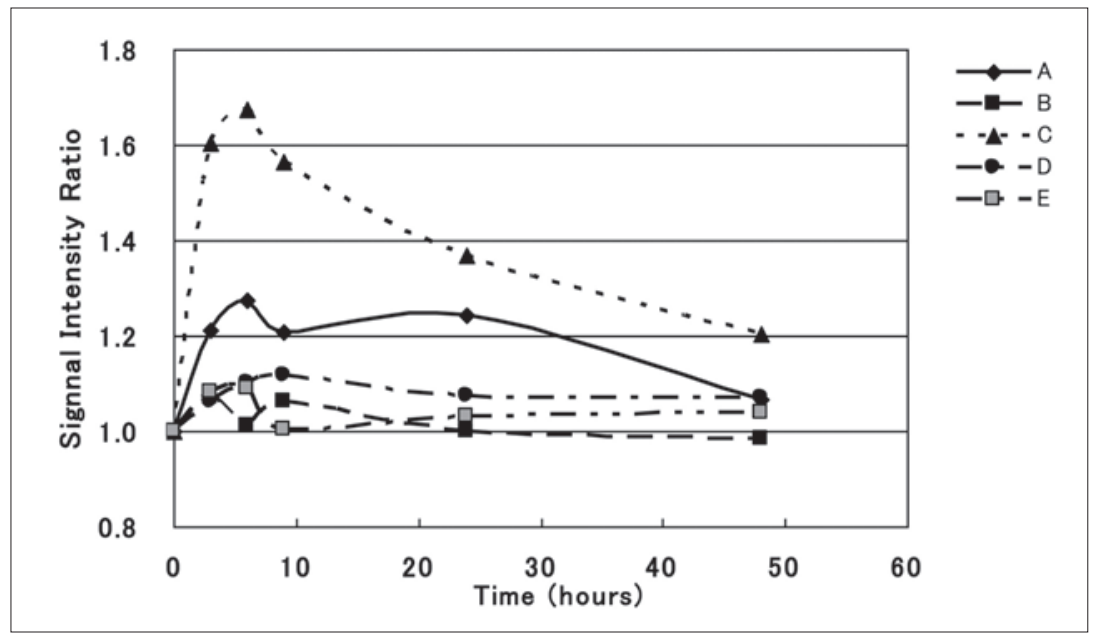

Fig. 4 The signal intensity ratio after the SPIO administration of a vertebral body and an intervertebral disk.

The signal intensity ratio was measured before the administration of SPIO for five volunteers $(A, B, C, D, E)$, and it was measured after the administration for 48 hours.

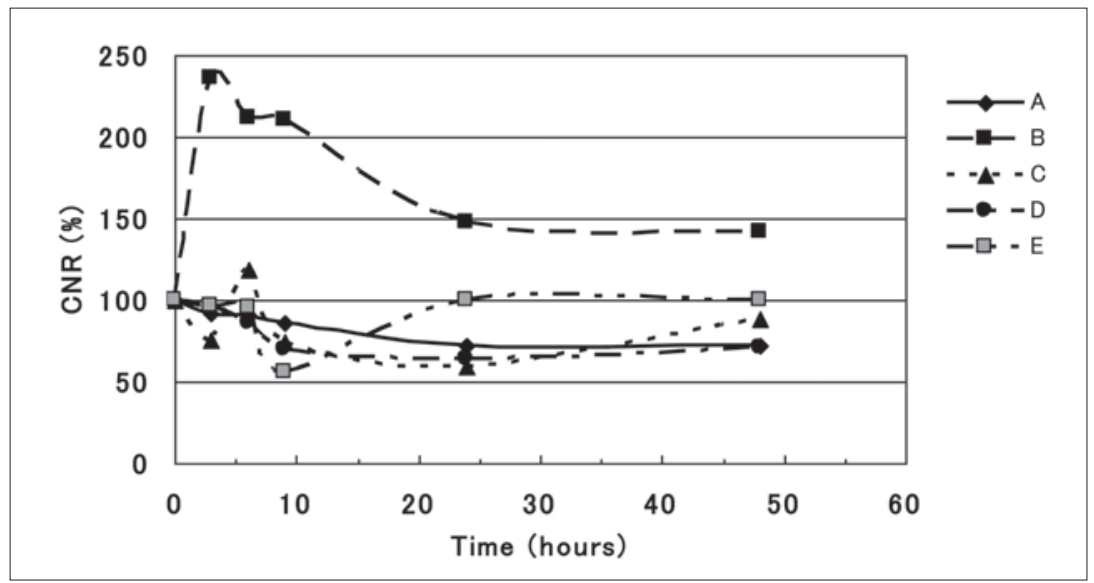

Fig. 5 CNR by the air signal method measured for each volunteer.

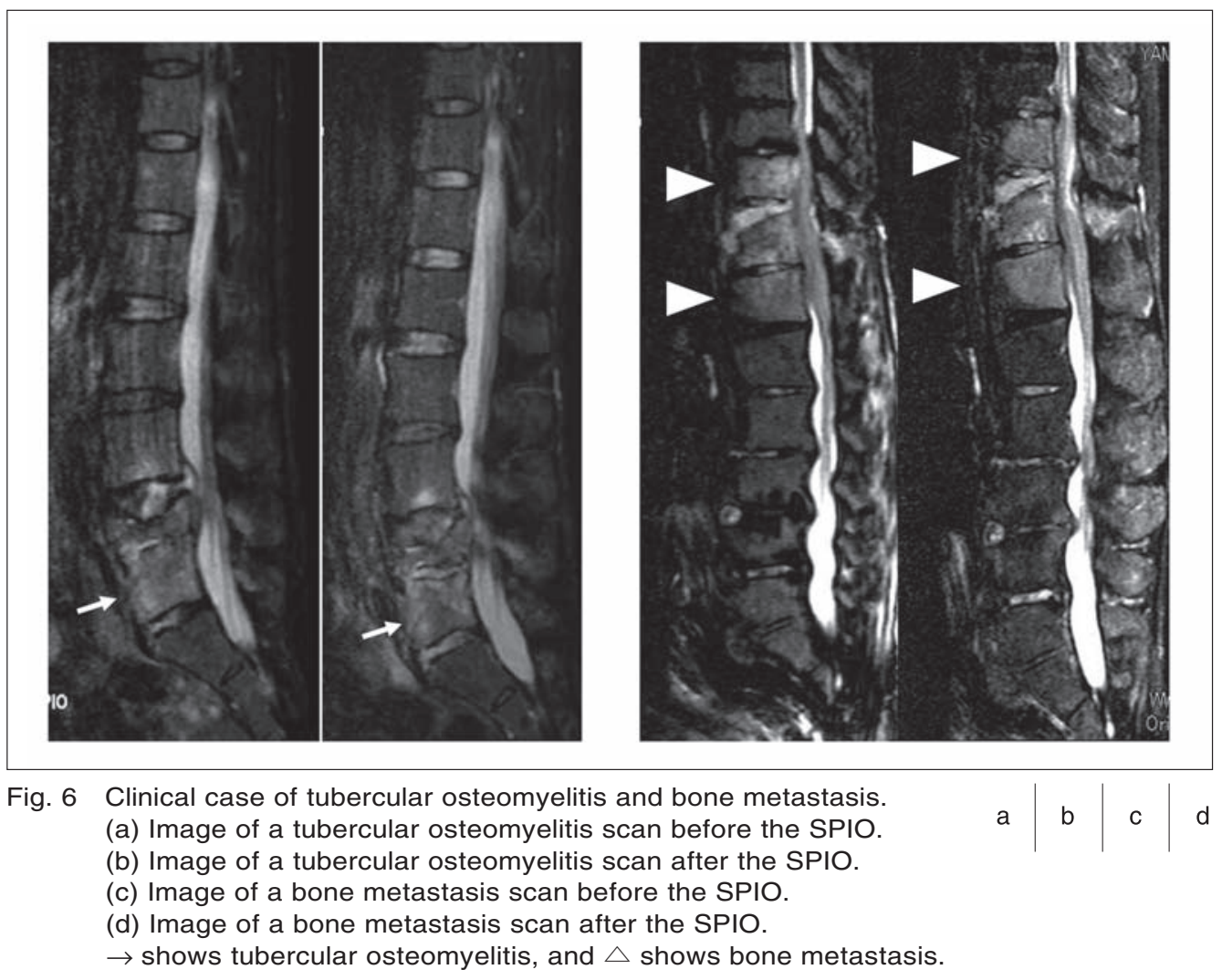




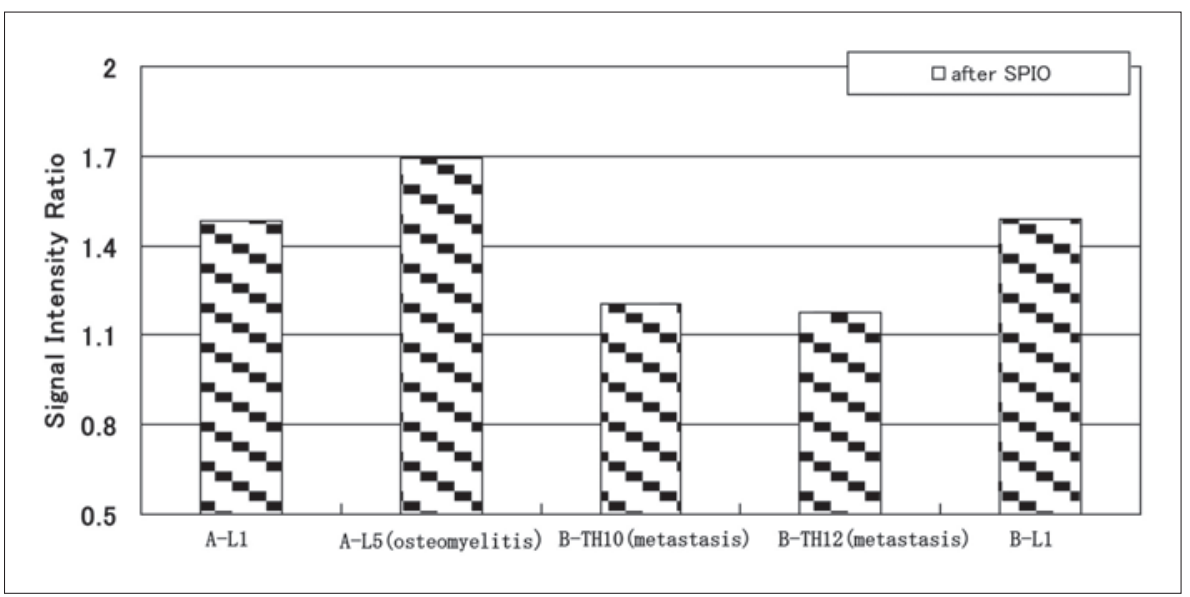

Fig. 7 The signal intensity ratio after the SPIO administration of tubercular osteomyelitis and vertebral body regions in bone metastasis and an intervertebral disk.

A refers to a single patient: A-L1 is a normal vertebral body, and A-L5 is a tuberculosis osteomyelitis.

$\mathrm{B}$ refers to a different patient: $\mathrm{B}-\mathrm{TH} 10$ and $\mathrm{B}-\mathrm{TH} 12$ are bone metastasis, and B-L1 is a normal vertebral body.

SPIO 投与後の SIR は, 正常椎体, 炎症性疾患椎体, 骨䯣転移椎体ともに上昇したが，炎症性疾患は正常 椎体よりも高值を示し，骨髄転移椎体は正常椎体より も低值を示した $(\mathrm{p}<0.02) .8$ 名の患者すべてに同様の 傾向があった。

\section{4-3＼cjkstart再現性と位置依存性の検証}

Fig. 8 に再現性の結果を示す。測定部位である第 3 腰椎と第 4 腰椎の椎体部は信号值で最大 35 の変動 が認められたが，等分散検定では分散比 5.24(P<0.05) であり，各椎体の再現性は同等と考えられる。

また, Fig. 9, 10 に水平および垂直方向への変化の 結果を示す。信号值は水平方向に最大 90 , 垂直方向 に最大 170 の変動がみられた。

\section{5. 考 察}

MRI の画像評価に用いられる CNRの測定法とし てさまざまなものが提唱されているが，臨床画像，ファ ントム画像などを評価する場合に，どの方法を用い ればよいのか明確になっていないのが現状である ${ }^{18)}$. パルスシーケンスや撮像パラメータを変化させて得ら れた画像の評価には CNR が用いられているが，本稿 では，造影剤投与前と投与後の画像コントラストの評 価が目的であるため, SPIO 造影剤の骨髄への取り达 みを利用した定量的解析法として信号值差分法を検 討した。 ボランティアによる測定では，規定量を投与 し，同じ測定をしたにも関わらず，測定值はさまざま な変化を呈した(Fig. 3)。したがって，SPIO 投与後の 信号值の大きさで造影効果を判断することは危険で あり，本法のように何らかの信号と比較評価する必要

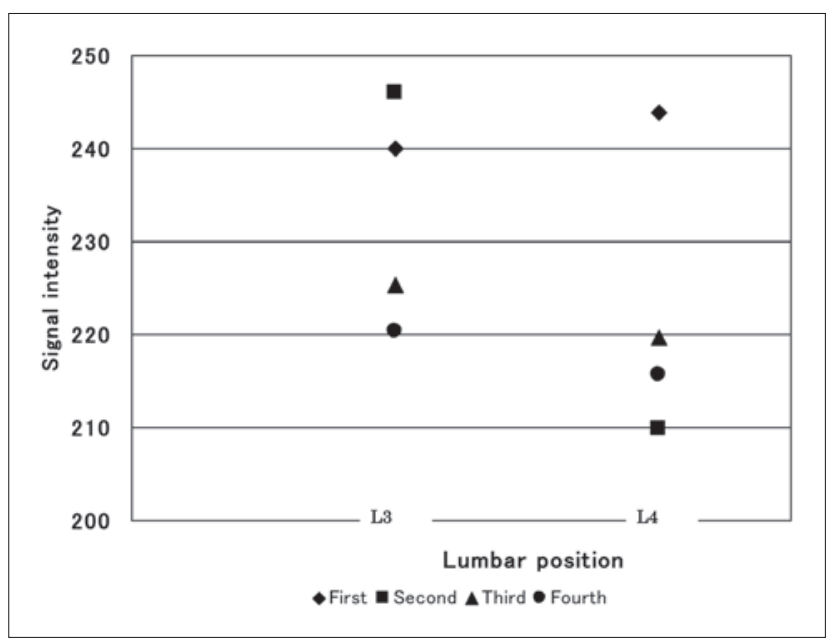

Fig. 8 Reproducibility of measured value. Points in the figure show dispersion of the signal intensity measured four times about the third lumbar vertebra (L3) and forth lumbar (L4) vertebra.

\section{があると考えられた}

正常骨髄が存在する椎体では，SPIO投与後の骨 髄信号の低下により椎間板部との信号差は大きくなり, 個人差はみられるものの，投与後 3 時間から 6 時間で 顕著に現れた(Fig. 4)。これは，正常な骨髄ではSPIO 造影剂の取り込みがあるため, SPIO 造影剤投与後の 骨髄信号が低下したものと推測される。この結果は, 臨床における撮像夕イミングとして有用であると考え られる。本法と空中信号法の結果を比較した場合に みられるばらつきの差は，空中信号法では算定に用 いるバックグランドの信号值の変動が影響を与えて いると考える。したがって, SPIO 造影剤の取り込み 


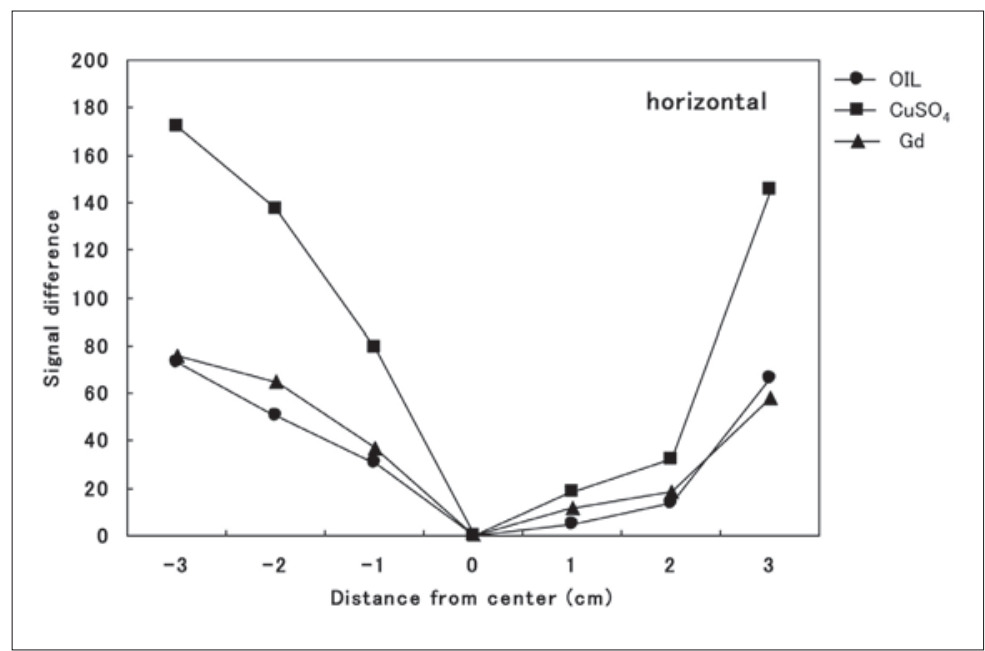

Fig. 9 Dependence of position in the horizontal direction about signal intensity.

The signal intensity imaged at increments of $1 \mathrm{~cm}$ to the left and right of the magnetic field center.

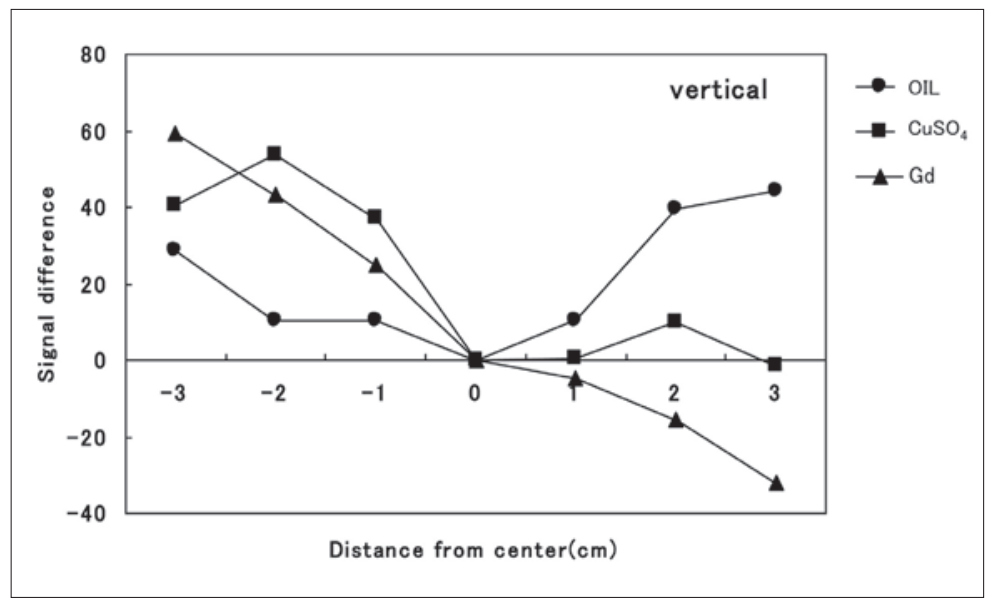

Fig. 10 Dependence of position in the vertical direction about signal intensity.

The signal intensity imaged at increments of $1 \mathrm{~cm}$ to the top and bottom of the magnetic field center.

を把握するには，本法が有用だと考える.

被写体のポジショニングにおける再現性では，被 写体位置により信号值で最大 35 の変動が認められ, 位置依存による影響と考えられた。しかし，測定椎 体近傍の椎間板を基準部位に用いているため，それ ぞれが同等の影響を受けており，有意差検定 $\mathrm{p}<0.05$ からも再現性が測定結果に与える影響は小さいと考 えられる。ただし，位置依存性の結果より再現性が 信号值に及ぼす影響は，位置依存性によるものが大 きいと考えられる。

このことから, ボランティアによる第 1 腰椎から第 5 腰椎の測定值のばらつき(標準偏差は 23 から 42 程度) の原因は，個体差によるばらつきよりも，第 1 腰椎か ら第 5 腰椎までにROI を設定した場合の測定位置依
存によるものと思われる.

椎間板は，理論的には造影されないとされているが, すべての被検者で造影効果が認められた(Fig. 3). し かし, 椎間板の造影効果は, 椎体に比べて低いため, 式(1)〜（4）の処理により，影響は相殺されると考えら れる. また, 変性を伴った椎間板の信号值であっても, 測定で用いるものが同一であるため, 同様に影響は 相殺されると考える.

また，本稿はSPIO 造影剤取り込み後の骨髄転移と 炎症性骨病変の信号強度比の傾向について検討して いるため，撮像条件に関してはFukudaらのものを7) 用い一定としたが, SPIO 造影剤の $\mathrm{T}_{2}$ 短縮効果の影 響を考慮すれば TE を変化させることにより信号強度に 変化がみられると考えられる。しかし, 骨髄の脂肪成分 
を抑制する TI を設定した $\mathrm{T}_{2}$ 強調画像としての STIR シーケンスを用いれば，目的とする骨髄転移と炎症性 骨病変の判定基準の傾向には影響はないと考える.

これらのことより，臨床における検討結果から本法 によるSIR が, 正常椎体よりも高い場合には炎症を 疑い, 正常值よりも低い場合には腫瘍を疑うという判 定基準に利用できることが示唆された。

\section{6. 結 語}

MRIの信号強度は，さまざまな因子に影響される ため，信号值を用いた評価を行うことが非常に困難 である。実験系においては，ノイズの測定が容易で 安定しているためSNR での評価が多く用いられてい るが，被写体がFOVのほぼ全域を占める場合のある 臨床ではノイズの測定が困難である。われわれは, 臨床においても信号值による客観的な評価を実現す るために，造影剤の影響を受けにくい部分を基準と する比較法を提案した。本法は, 位置依存性や装置 の感度変化の影響を受けにくく, SPIO 造影剤投与前
後の撮像で検査室への入退室が必要となる時間をお いた画像比較において，視覚評価(診断)では捉えに くい変化も，常に相対的比較が可能となり，臨床評 価に有用な方法であることが分かった。また，本法の 証明に用いたSPIO 造影剤は，本来肝臓特異性造影 剂であり現状では骨髄等への使用は診療報酬上認めら れておらず，臨床応用には問題が残るが，肝腫瘍の 検出のみならず，臨床上鑑別がつきにくい骨髄腫瘍 と炎症性疾患の判定にも有用であることが証明され た。今後，更なる SPIO 造影剤の粒子の細密化による 取り込み率の向上などを期待して，本法が役立てら れればと考える.

\section{謝 辞}

稿を終えるにあたり，本研究にご協力いただきました 兵庫医科大学病院中央放射線部の放射線技師諸兄, バイエル薬品株式会社の豊田 健氏, 津田奈津子氏 に深謝いたします。

\section{参考文献}

1) 谷本伸弘. 肝特異性造影剂現状と今後の展望. 日本医放 会誌 2001; 61(10): 525-533.

2) 谷本伸弘. SPIO 造影 MRI. 肝の最新 MRI. 金原出版, 東京, 2004: 113-166.

3) 徳山武一, 森田達郎, 新井健史, 他. 肝特異性 MRI 造影 剂フェルカルボトランの至適撮像条件の検討。日磁医誌 2003; 23(S): 73.

4）荒木 力, 村上卓道, 市川智章, 他. 腹部の MRI. メディ カル・サイエンス・インターナショナル, 東京, 2000; 11.

5) Murakami T, Baron RL, Federle MP, et al. Cirrhosis of the liver: MR imaging with mangafodipir trisodium (Mn-DPDP). Radiology 1996; 198(2): 567-572.

6) Tsuda N, Tsuji T, Kato N, et al. Potential of Superparamagnetic Iron Oxide in the Differential Diagnosis of Metastasis and Inflammation in BoneMarrow. Invest Radiol 2005; 40(10): 676-681.

7) Fukuda Y, Ando K, Ishikura R, et al. Superparamagnetic iron oxide (SPIO) MRI contrast agent for bone marrow imaging: differentiating bone metastasis and osteomyelitis. Magn Reson Med Sci 2006; 5(4): 191-196.

8）上谷雅孝, 麻生伸哉, 川原康弘, 他. 骨軟部疾患の画像 診断。秀潤社, 東京, 2002: 191.

9) Lawaczeck R, Bauer H, Frenzel T, et al. Magnetic iron oxide particles coated with carboxydextran for parenteral administration and liver contrasting. Pre-clinical profile of SH U555A. Acta Radiol 1997; 38(4 Pt 1): 584-597.

10）宇田川信之．破骨細胞の形成を調節する ODF 遺伝子. 85
CLINICIAN' 1999; 480.

11) Weissleder R, Stark DD, Engelstad BL, et al. Superparamagnetic iron oxide: pharmacokineteics and toxicity. AJR Am J Roentgenol 1989; 152(1): 167-173.

12) Oswald $P$, Clement $O$, Chambon $C$, et al. Liver positive enhancement after injection of superparamagnetic nanoparticles: respective role of circulating and uptaken particles. Magn Reson Imaging 1997;15(9): 1025-1031.

13) Chambon $C$, Clement $O$, Le Blanche A, et al. Superparamagnetic iron oxides as positive MR contrast agents: in vitro and in vivo evidence. Magn Reson Imaging 1993; 11(4): 509-519.

14）吉瀬 哲, 多々井久徳, 蜂屋順一, 他. MRI 応用自在. メジカルビュー社, 東京, 2002: 101-105.

15) 日本放射線技術学会編. 放射線医療技術学叢書(18) MR 撮像技術。日本放射線技術学会，京都，2000；213-215， 229-230.

16）小倉明夫，宮井 明，前田富美恵，他．MR 画像の SNR 測 定に関する基礎的検討. 日放技学誌 2003; 59(4): 508-513.

17）小倉明夫, 前田富美恵, 宮井 明, 他. MR 臨床画像の CNR 測定法に関する精度。日放技学誌 2004; 60(11): 1543-1549.

18）和田陽一, 原 孝則, 宮地利明. MRI システムのファン トムに扔ける CNR 測定法の基礎評価一改良 CNR 評価法 の提案. 日放技学誌 2007; 64(2): 268-276.

19) Michelson AA. Studies in Optics. Chicago: University of Chicago Press, 1927. 


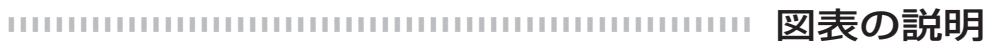

Fig. 1 椎体と椎間板における ROI の設定

$\mathrm{BM}_{\mathrm{nor}}$ は正常椎体部, $\mathrm{BM}_{\mathrm{abnor}}$ は異常椎体部, D は椎間板.

Fig. 2 位置依存性評価に使用したファントム(硫酸銅溶液，モル濃度 $0.0025 \mathrm{~mol} / 1 \mathrm{Gd}-\mathrm{DTPA}$ ，オリーブオイル)

Fig. 35 名のボランティア (A， B， C，D，E)に扔けるSPIO 投与前と投与後 48 時間までの椎体部，椎間板の信号值(椎体部は第 1 腰椎から第 5 腰椎の平均值)

Fig. 45 名のボランティア $(\mathrm{A}, \mathrm{B}, \mathrm{C}, \mathrm{D}, \mathrm{E})$ における SPIO 投与前と投与後 48 時間までの椎体部, 椎間板の信号強度比

Fig. 5 各ボランティアに扔ける空中信号法での CNR

Fig. 6 結核性骨髄炎と骨転移の臨床例
(a) SPIO 投与前の結核性骨髄炎
(b) SPIO 投与後の結核性骨髄炎
(c) SPIO 投与前の骨転移
(d) SPIO 投与後の骨転移
図中の $\rightarrow$ は結核性骨髄炎を, $\triangle$ は骨転移を示す。

Fig. 7 結核性骨髄炎と骨転移における椎体部と椎間板の信号強度比

A-L1 は正常椎体，A-L5 は結核性骨髄炎の投与後の比較，B-TH10 および B-TH12 は骨転移，B-L1 は正常椎体の投与後の 比較を示す。

Fig. 8 測定值の再現性

第 3 腰椎と第 4 腰椎を 4 回測定した信号値の変化.

Fig. 9 水平方向での位置依存性

磁場中心から左右方向に $1 \mathrm{~cm}$ ずつ移動させて撮像した信号值.

Fig. 10 垂直方向での位置依存性

磁場中心から頭尾方向に $1 \mathrm{~cm}$ ずつ移動させて撮像した信号値. 